Годишњак Филозофског факултета у Новом Саду, Кьига ХХХІХ-2 (2014)

Annual Review of the Faculty of Philosophy, Novi Sad, Volume XXXIX-2 (2014)

Ana Makišová

Filozofická fakulta Univerzita v Novom Sade

UDK 811.162.4‘373.232.1:003.035

Originalan naučni rad

\title{
ZAPISOVANIE SLOVENSKÝCH PRIEZVISK V SLOVENSKOM A V SRBSKOM KONTEXTE ${ }^{1}$
}

V práci sme výskum zamerali na zapisovanie slovenských priezvisk v srbskom kontexte. V súčasnosti je medzi vojvodinskými Slovákmi aktuálnym problémom prepis slovenských priezvisk do srbčiny. V príspevku sme sa zamerali na transkribovanie niektorých slovenských grafém do srbčiny. Naznačili sme rozdiely pri transkribovaní, ktoré sa uvádzajú v normatívnych príručkách a ako je to v praxi. Uviedli sme aj zapisovanie slovenských mien a priezvisk do úradných dokladov v srbskom jazyku. V druhej časti sme sa zamerali na tvorenie prechýlených podôb nielen slovenských priezvisk, ale aj inojazykových v slovenskom kontexte a prípadné odklony. Mužské priezviská majú najčastejšie formu substantív ako pomenovaní samostatne existujúcich substancií. Len zriedka majú adjektívnu podobu. Ženské priezviská majú všetky formu privlastňovacieho prídavného mena na -ova/-ová/-a. V d’alšej časti v príspevku sme sa zamerali na používanie priezvisk v slovenskom kontexte v každodennej praxi.

Klúčové slová: priezvisko, slovenský jazyk, srbský jazyk, prechýlená podoba

V príspevku sa zameriame na zapisovanie a používanie slovenských a srbských priezvisk vo Vojvodine. Pozornost' upriamime v prvom rade na slovenské priezviská, ktoré sa používajú vo vojvodinskom prostredí, ako ich zapisujeme do úradných dokladov - máme tu na mysli úradný srbský jazyk, teda ako ich transkribujeme. Ďalej svoj výskum upriamime na to, ako sa spomenuté priezviská používajú v slovenskom kontexte v každodennej praxi, bud’to v škole, v tlačených resp. písaných médiách, $\mathrm{v}$ úradných dokladoch a $\mathrm{v}$ iných oblastiach. Rovnako tak je pre nás dôležité aj používanie srbských priezvisk v slovenskom kontexte - najmä ženské, prechýlené podoby priezvisk.

V odbornej literatúre o priezviskách, ktoré sú frekventované vo vojvodinskom prostredí, písal lingvista a dialektológ Daniel Dudok. V rámci svojho výskumu spomenutý odborník sa vo výskume zameral na etymológiu jednotlivých priezvisk. V monografii Priezviská Slovákov v Juhoslávii sú zoradené priezviská, ktoré sú aktuálne v súčasnosti ale aj tie, ktoré už pomaly zanikli. V spomenutej monografii sa píše o histórii pomenovania osôb, o slovenských priezviskách, o priezviskách Slovákov vo Vojvodine vo vzt’ahu k priezviskám na Slovensku. Najviac priestoru autor venoval slovnodruhovému a významovému triedeniu a rozboru zozbieraných

Makisova.anna@gmail.com

Príspevok vznikol v rámci projektu č. 178017 Diskurzy menšinových jazykov, literatúr a kultúr v juhovýchodnej a strednej Európe, ktorý financuje Ministerstvo školstva a vedy Srbska. 
priezvisk. Osobitnú čast' tvorí register priezvisk, ktorých je celkove vyše 4200 . Vedl'a každého priezviska je uvedená osada, v ktorej sa priezvisko vyskytuje. Ide o monografiu, v ktorej sú najkompletnejšie a najvšestrannejšie preskúmané vojvodinské slovenské priezviská. V štúdii Pôvod Hložančanov z hladiska ich priezvisk, ktorá je uverejnená v zborníku prác Hložany 3, sa profesor Daniel Dudok zameral na výskum priezvisk v spomínanej osade. Autor štúdie uvádza priezviská, ktoré sa vyskytli v Hložanoch za posledných 125 rokov. Podáva význam slov a tvarov, z ktorých vznikli jednotlivé priezviská. Autor vedl’a každého priezviska uvádza aj d’alšie osady vo Vojvodine, v ktorých sa spomínané priezvisko vyskytuje. Problematike priezvisk sa čiastočne venoval aj lingvista profesor Michal Týr v štúdii Meno a národná identita. Autor v jednej časti štúdie výskum venoval menu, ale sa zmienil aj o tvorení ženských podôb priezvisk v slovenčine. Aj po desiatich rokoch, kedy bola uverejnená spomenutá štúdia, je uvedená problematika ešte stále aktuálna.

Priezviská z morfologického aspektu sú spracované v Morfológii slovenského jazyka. Čiastočne o priezviskách písal aj Martin Ološtiak v štúdii Slovotvorba prevzatých vlastných mien $v$ slovenčine II. Autor sa zameral na výskum vlastných mien cudzieho pôvodu, ktoré sú čoraz častejšie v slovenskom jazyku. Spomenutý lingvista z morfologického aspektu skúmal antroponymá, toponymá a chrématonymá v štúdii Morfológia vlastných mien, ktorá je osobitnou statou kolektívneho diela Morfologické aspekty súčasnej slovenčiny. V tomto kontexte treba spomenút' aj odborníka onomastika Milana Majtána, ktorý sa venoval skúmaniu priezvisk na Slovensku. Ešte je čerstvá monografia Naše priezviská, ktorá bola vydaná pri príležitosti autorových 80. narodenín, ked’ bola v Bratislave usporiadaná aj 19. slovenská onomastická konferencia, venovaná významnému životnému jubileu Milana Majtána. Autor skúmal tvorenie priezvisk z krstných mien, podl’a príbuzenských vzt'ahov, podla zamestnania, z obyvatel'ských mien... Vel'mi vzácny je abecedný slovník. V uvedenej monografii autor píše o prechyl’ovaní priezvisk, tvorení ženských podôb, ktoré je príznačné pre slovanské jazyky.

Národnostné menšiny v Republike Srbsko majú právo používat' svoj jazyk a písmo $\mathrm{v}$ oblasti vzdelávania, $\mathrm{v}$ prostriedkoch verejného informovania, $\mathrm{v}$ administratívno-právnej oblasti, v oblasti náboženstva a pod. Všetky spomenuté oblasti sú regulované rôznymi právnymi predpismi. Ústavou Republiky Srbsko je regulované, že úradným jazykom je srbčina, písmo cyrilika. Zákonom sa upravuje úradné používanie iných jazykov. Príslušníci národnostných menšín majú právo na používanie vlastného jazyka a písma, a to najmä v tých oblastiach, kde tvoria väčšinu. V takých oblastiach sa uplatňuje právo na vyučovanie v svojom rodnom jazyku, právo používat' jazyk menšiny $\mathrm{v}$ úradnom styku v miestnych orgánoch samosprávy a právo na používanie materinského jazyka aj v iných sférach verejného života. Rovnako tak ústava zaručuje aj právo príslušníkom národnostných menšín používat' meno a priezvisko vo svojom jazyku a právo dvojjazyčného označenia tradičných miestnych názvov, názvov ulíc, osídlení a topografických značiek nielen $\mathrm{v}$ oficiálnom jazyku, ale aj v jazyku národnostnej menšiny. 
Štatútom Autonómnej pokrajiny Vojvodiny sú regulované práva národnostných menšín používat' jazyk a písmo. Podla Zákona o ochrane práv a slobôd národnostných menšín (Lomianský, 2006,14) príslušníci národnostných menšín majú právo používat' osobné meno a meno svojich detí a rovnako tak aj zapisovat' do všetkých verejných dokladov podla jazyka a pravopisu príslušníkov národnostnej menšiny. Príslušník národnostnej menšiny má právo svoje osobné meno a osobné mená svojich detí zapísat' do matričnej evidencie v pôvodnej podobe, v písme a podla pravopisu svojho jazyka. Lenže v praxi je to trochu odlišné. Ako zapísat' meno a priezvisko $\mathrm{v}$ pôvodnej podobe, ak matrikár nepozná pravopis - konkrétne slovenský. Lebo zvyčajne zápis do matriky narodených je nie vždy na mieste, kde sú matrikári, ktorí poznajú a ovládajú pravopis všetkých národnostných menšín, ktoré žijú na území Vojvodiny (aj ked'v minulosti konkrétne matrikármi boli aj osoby z radov slovenskej príslušnosti v Novom Sade). A z toho potom d'alej vyplýva, že ak je osobné meno a priezvisko príslušníkov národnostných menšín zapísané v matrike narodených $\mathrm{v}$ pôvodnej, slovenskej podobe, $\mathrm{v}$ tej podobe a rovnakým spôsobom sa zapíše aj do verejných dokladov (osobného preukazu, do žiackej knižky, cestovného dokladu, vodičského preukazu, diplomu a pod.) a v tej podobe sa bude d'alej používat'.

Aktuálnym problémom je prepis slovenských priezvisk do srbčiny, zapísaných latinkou alebo cyrilikou. V súčasných podmienkach často vzniká niekol'ko možných variantov toho istého priezviska. V slovenčine existujú presné pravidlá podla ktorých zapisujeme „oproti písmenu jednej abecedy stojí písmeno alebo aj viacero písmen druhej abecedy podla výslovnosti na istom mieste. Tento spôsob prepisu sa v našom jazyku používa bežne a volá sa transkripcia.“ (Pravidlá slovenského pravopisu, 2000, 42) tak napr. priezvisko Kolesár môže byt' zapísané po srbsky už či cyrilikou alebo latinkou, môže mat' viac variantov bez zmäkčovania Kolesar alebo Koljesar vyznačené spoluhláskou lj ked’že v slovenčine neoznačujeme mäkkú spoluhlásku. V tomto prípade ide jednoducho len o vec poznania slovenského jazyka, pravopisu a pravidiel. Ked’že som bola jednou z členiek autorského tímu (Marićová, Týr, Týrová), ktorý vypracoval príručku Transkripcia priezvisk zo slovenčiny do srbčiny, môžem konkrétne poukázat' ako je to v praxi a ako je to v normatívnej príručke Pravopis srpskoga jezika (2013). Na strane 231 sa uvádzajú pravidlá transkribovania zo slovenčiny do srbčiny. Kto pozná pravidlá slovenského pravopisu a pravidlá slovenskej ortoepie vie, že nie všetky pravidlá transkripcie sa dajú uplatnit' podl'a normatívnej príručky Pravopis srpskoga jezika.

Zmienim sa v krátkosti ako sme postupovali pri transkribovaní jednotlivých slovenských písmen do srbčiny. Ked' ide o písmená, ktoré majú mäkčeň: d', t', l', n̆ sme zapisovali takto, (ked' to bolo latinkou): đ. V tomto kontexte treba pripomenút', že transkripcia je spracovaná v príručke Pravopise srpskoga jezika (2013) kde sa uvádza, že slovenskú spoluhlásku d' do srbčiny transkribujeme ako dj vtedy, ak stojí pred samohláskou. Nepostupovali sme tak ako je to zapísané v normatívnom diele Pravopis srpskoga jezika, lebo poznáme hláskoslovný systém srbského ja- 
zyka a dobre vieme, že slovenskej hláske d' je v srbčine ekvivalentné písmeno đ (latinka) Ђ (cyrilika). Nie je jedno či zapíšeme Đalog alebo Djalog, Đurik alebo Djurik, Bađonski alebo Badjonski, sú to varianty priezviska, ktoré sa čítajú rozdielne. Spoluhlásky d' a đ sa navzájom líšia vo výslovnosti - v slovenčine je to záverová a v srbčine polozáverová spoluhláska. Sme presvedčení, že je prijatel'nejšie vyslovovat' jednu spoluhlásku (đ) než dve (dj) a aj význam priezviska sa nemení. V prípade, že sa slovenské d' vyskytne na konci slova, vtedy podla Pravopisu srpskoga jezika sa píše iba d. My sme však postupovali inak, považovali sme za potrebné mäkkost' označit', a preto sme písali đ aj na konci priezviska, napr. Medveđ. Ak po d' nasledovala samohláska e, typu Dend'úr transkribovali sme to ako srbské Đ latinkou a $\mathrm{h}$ cyrilikopu, lebo sme považovali za dôležité označit' mäkkost' spoluhlásky. Hlavným dôvodom bolo rozlíšit' dve hlásky d a d', lebo výslovnost' Dend'úr a Demák je rozdielna (pri priezviskách cudzieho pôvodu výslovnost' je tvrdá a to sa dodržiavalo aj pri transkribovaní do srbčiny). Ak po spoluhláske d nasleduje i, podla normatívnej príručky sa zapisuje di, teda bez označenia mäkkosti. Aj v tomto prípade sme odstúpili od pravidiel normatívnej príručky a na označenie mäkkosti pred samohláskou i sme používali grafému đ, napr. Đinja, Đivjak, Prebuđila, Đerđ a grafému d sme zapisovali na miestach, kde máme tvrdú výslovnost' (Dingo, Dinga, Dišpiter).

Slovenskú grafému t' sme transkribovali ako ć, (c s čiaročkou hore), resp. † v polohe ked' po spoluhláske nasleduje samohláska, napr. Folćan, Šćastni. Rovnako aj v pozícii na konci slova $\mathrm{t}^{\prime}=\mathrm{c}$, resp. $\hbar$, napr. Janać. Ked' po spoluhláske $\mathrm{t}$ nasledovali samohlásky e, i, í, ked' bolo potrebné vyznačit' mäkkost', vyznačili sme to grafémami a fonémami ć, resp. ћ, napr. Ćepli, Marćišs, Ćihi, Ćeplica, Ćehonj, Cihonj. V prípade, ked' máme tvrdú výslovnost', vtedy sme to aj vyznačili takto: Martinko, Tir, na označenie tvrdej spoluhlásky použili sme jednoducho grafému t. Podl'a normatívnej príručky srbčiny sa slovenská graféma t'v srbčine zapisuje, transkribuje ako tj, napr. Tekov ako Tjekov. V pozícii na konci slova slovenská spoluhláska t' sa podla transkripcie do srbčiny transkribuje ako t. Pracovný tím pri vypracúvaní transkripcie priezvisk sa nepridržiaval uvedených normatívnych zásad, ale postupoval podl’a hore uvedeného.

Slovenskú grafému l' sme transkribovali do srbčiny ako lj vo všetkých pozíciách a to na konci slova, napr. Pribelj, Tarcalj, ked' po spoluhláske nasledovala samohláska a, napr. Martulja, Ljavko, Ljavo, Kraljovski a v pozícii, ked' v slovenčine máme zmäkčovanie, typu Ljiška, Lješćan, Lješćanski, Ljevarski, Ljenjo. V srbskej kodifikačnej príručke píše, že ak po spoluhláske l' nasleduje i, v tejto pozícii píšeme písmeno l. Považovali sme za potrebné vyznačit' rozdiel medzi priezviskami, kde vo výslovnosti nastáva zmäkčovanie, typu Litavský, Liška, Lipták oproti Lilge, Listmajer, Lichner.

Slovenskú grafému n̆ sme transkribovali ako nj v pozícii na konci slova, napr. Nosanj, Leginj, ked' po spoluhláske ň nasleduje samohláska, napr. Pnjak, Tornjoš ale aj v pozícii, kde máme v slovenčine zmäkčovanie, ked' nepíšeme mäkčeň, napr. 
Njespal, Njemčok, Janjik, Danjiš, Krasnjec, Jamnjicki, Senjicki. Rovnaká situácia je aj podla pravidiel srbského jazyka.

Slovenské dvojhlásky ia, ie sa do srbčiny zapisujú podl’a pravidiel ako ja, je, ked' nasledujú po spoluhláskach okrem 1 a n. Tu musíme pripomenút', že inak treba zapisovat' aj dvojhlásky, ked' nasledujú po spoluhláskach d, t (to sa v pravidlách neuvádza). Doklady, ked' dvojhlásky nasledujú nie po d, t, $1, \mathrm{n}$, napr. Babjak, Čjef, Črjepok, Čjerni, Gjerik, Bičjar, Trjaška, Tušjak, Spišjak, Ušjak, Bjelčik. Ked' po spoluhláskach d, t, 1, n, nasledujú dvojhlásky ia, ie do srbčiny sa prepisujú takto: priezvisko Dierčan sme zapísali takto: najprv sme vyznačili mäkkú spoluhlásku na začiatku slova Đ a dvojhlásku ie sme zapísali s je, teda Đjerčan paralelne máme vyznačené zmäkčovanie tak, že sme to zapísali mäkkou spoluhláskou a transkribovali sme spoluhlásku ie ako je. Ked' po spoluhláske t nasledovala dvojhláska ie, vyznačili sme to takto: mäkkost' sme vyznačili spoluhláskou ć a dvojhlásku ie sme prepísali ako je: Ćješko, Ćješok, Trsćjanski, Kašćjak, Trećjak. Ked' po spoluhláske 1 nasledovali dvojhlásky ia, ie, zapisovali sme ich ako ljija, ljije, lebo v srbčine nie je možná kombinácia ljj Martuljijak, Beljijanski, Ljijetaj, Poljijak, Tatljijak. Ked' po spoluhláske n nasledovali dvojhlásky ia, ie zapísali sme to takto: Korunjijak, Hornjijak.

V Pravopise srpskoga jezika sa neuvádza prepis písmena ä. V srbčine pri transkripcii samohláska ä má svoj ekvivalent e. Pri našom výskume sme sa stretli len s dvoma priezviskami, v ktorých sa vykytla spomenutá samohláska a to Mesjar a Mesjarik.

Ypsilon sme zapisovali ako obyčajné i bez zmäkčovania predchádzajúcej spoluhlásky, napr. Čjerni, Hrubi, Bađ̋onski, Ribarski, Tir, Mijavec, Semartonski.

Slovenskú spoluhlásku dž do srbčiny sme transkribovali rovnako ako aj v slovenčine, dž. Zo slovenských vojvodinských priezvisk spoluhláska dž sa vyskytla iba v dvoch priezviskách Pivardži a Vardžik.

Slovenskú spoluhlásku ch v srbčine sme zapisovali h, Hlpka, Halupka, Hrenko, Hrćan, Hljipec. Ked’že srbčina nepozná hrtanovú spoluhlásku h, aj túto sme do srbčiny transkribovali rovnako ako aj predchádzajúcu, h: Hrubik, Halabrin, Habor, Hanulja, Harpanj, Haška. Preto slovenské priezviská, v ktorých sa vyskytujú spoluhlásky h a ch, pri transkribovaní do srbčiny rovnako znejú: Hlpka-Hrubik.

Dvojhlásku ô sme transkribovali ako vo: Nôta $\rightarrow$ Nvota.

Dížka samohlásky v slovenčine je fonologicky dištinktívna vlastnost' a označuje sa dížňom nad samohláskou, napr. Bílek, Fábry, Hrubík, Klátik, Litavský, kým v srbčine uvedená vlastnost' sa nevyjadruje, rovnako píšeme aj krátke, aj dlhé samohlásky.

Ďalej sa zmienime o tvorení prechýlenej podoby priezvisk.

Pri tvorení prechýlenej, ženskej podoby priezviska sme zistili, že v praxi vel'mi často nastávajú odchýlky od spisovnej normy. A to nielen v ústnej podobe, ale aj v písomnej podobe. Čo však neznamená, že každá príslušníčka slovenského jazykového spoločenstva si svoje priezvisko zapisuje a používa v prechýlenej podobe. Ale už ked' áno, tak nech je to podl'a pravidiel, ktoré platia v slovenčine. 
V slovenčine kodifikačné príručky prvýkrát zaviedli prechýlenú ženskú podobu priezviska v Pravidlách slovenského pravopisu z roku 1931 (s. 42 - 43) predovšetkým $\mathrm{v}$ domácich priezviskách. Uvádza sa prechylovacia prípona -ová. Aj v d’alších vydaniach sa píše o prechylovaní domácich priezvisk, ale aj cudzích priezvisk. V súčasnosti nevyhnutnou pomôckou pri prechylovaní priezvisk sú nám Pravidlá slovenského pravopisu z roku 2000. Spomenutá problematika je spracovaná na stranách 127-128.

Priezvisko plní identifikačnú funkciu. Podl’a Pravidiel slovenského jazyka osoby ženského pohlavia by mali mat' prechýlené priezviská, t.j. priezviská zakončené na -ová/-á/-a. Skutočnost' je však iná, v praxi niekedy nastáva odklon od spisovnej normy. Ked' ide najmä o zapisovanie do matriky narodených sú dvojaké možnosti. Bud’to sa zapíše tá základná, neprechýlená podoba alebo tá prechýlená a od toho potom závisí, ktorá bude odstránená tá úradná podoba.

Ženské priezviská sa tvoria od mužských pridaním koncovky. Mužské priezviská majú najčastejšie formu substantív ako pomenovaní samostatne existujúcich substancí́. Len zriedka majú formu prídavného mena.

Ked' sa ženské priezvisko tvorí z mužského priezviska, ktoré má tvar podstatného mena a základ sa končí na spoluhlásku, typu Macák - Macáková, Oros Orosová, Petrík - Petriková, Šeprák - Šepráková, nenastávajú odklony pri tvorení a používaní prechýlenej podoby vo vojvodinskom prostredí.

1.1. Ak sa mužské priezvisko končí na -ec, -ek, -ok pri tvorení prechýlenej ženskej podoby nastáva striedanie e/ø, o/ø. Odklony sme nezaznamenali Dudok - Dudková, Škulec - Škulcová, Zvarec - Zvarcová.

1.2. Ak sa mužské priezvisko končí na -ec, -ek, -ok, pred ktorým je spoluhláska alebo skupina spoluhlások, nenastáva striedanie e/ø, o/ø, lebo by vznikla t’ažko vyslovitel'ná skupina spoluhlások, napr.: Balček - Balčeková Bartok-Bartoková, Buzek - Buzeková, Knapček - Knapčeková, Krasnec-Krasnecová, Pavčok - Pavčoková, Suchánek - Sucháneková.

1.3. Ak sa mužské priezvisko končí na samohlásku -a alebo -o prechýlené ženské priezvisko sa tvorí pridaním prípony -ová, pričom sa koncové samohlásky -o, -a odsúvajú, napr.: Bako - Baková, Barca - Barcová, Kičiňa - Kičiňová, Krasko - Krasková, Macko - Macková, Macho-Machová, Marko-Marková, Mala - Malová, Vrana - Vranová, Zima - Zimová, Žiška - Žišková. Pri tvorení prechýlenej podoby sme odklony od spisovnej normy nezaznamenali.

1.4. Mužské priezviská, ktoré sa končia na -ov, majú podobu privlastňovacích prídavných mien, nie sú vo vojvodinskom prostredí frekventované. V našom výskume sme zaznamenali tieto: Antov, Apostolov, Beňov, Cmárov, Ďurov, Ďurkov, Fetisov, Jančov, Janšov, Kaňov, Kozov, Krajčov, Križov, Ondrejov, Pavlov, Šimov, Števkov. Prechýlené ženské podoby sa tvoria pridaním koncového -ová k celému tvaru mužskej podoby: Antovová, Apostolovová, Beňovová, Cmárovová, Ďurovová, Ďurkovová, Fetisovová, Jančovová, Janšovová, Kaňovová, Kozovová, Krajčovová, Krížovová, Ondrejovová, Pavlovová, Šimovová, Števkovová. V praxi, v každodennom používaní, pri tomto type priezvisk nastáva odklon od spisovnej 
normy. Namiesto pridania koncového -ová vel'mi často sa ženská prechýlená podoba tvorí pridaním iba -á, napr. Križová, Pavlová, Števková, ov sa vynecháva, lebo nastávajú pochybnosti, že sa opakuje koncové ov, ktoré je súčastou základu a vyskytuje sa aj v prechýlenej prípone. Takéto nenáležité podoby sa často vyskytujú zapísané v úradných dokladoch.

1.5. Osobitnú podskupinu tvoria mužské priezviská, ktoré sa v mužskom tvare končia na mäkké -i, napr.: Belaji, Čáni, Dóci, Durandzi, Fejdi, Francisci, Gabríni, Gáni, Kostoláni, Krajči, Meši, Parkáni, Salaji, Šepši, Šimoni, Šomodi, Tárnoci, Turóci, Uheli, Vizi, Žemberi, Žilaji. V spisovnej slovenčine ženské prechýlené podoby sa tvoria pridaním koncového -ová na mužskú podobu priezviska, napr.: Belajiová, Čániová, Dóciová, Durandziová, Fejdiová, Francisciová, Gabríniová, Gániová, Kostolániová, Krajčiová, Mešiová, Parkániová, Salajiová, Šepšiová, Šimoniová, Šomodiová, Tárnociová, Turóciová, Uheliová, Viziová, Žemberiová, Žilajiová. Aj pri tomto type ženskej podoby často nastáva odklon od spisovnej normy, pri tvorení prechýlenej ženskej podoby sa vynecháva koncová samohláska -i, v praxi sa vel'mi často stretneme s podobami Čáňová, Fejd'ová, Salajová, Šepšová, Tárnocová, Turócová.

1.6. Ďalšiu podskupinu tvoria priezviská, ktoré sa $v$ mužskom tvare končia na tvrdé krátke -y, napr.: Ededy, Fábry, Francisty, Teleky, Torday, Zolnay, Žembery, Žilay. Prechýlená ženská podoba sa tvorí pridaním koncového -ová na celú podobu mužského priezviska: Ededyová, Fábryová, Francistyová, Telekyová, Tordayová, Zolnayová, Žemberyová, Žilayová. Podobne ako aj v predchádzajúcej podskupine priezvisk, pri tvorení prechýlenej podoby nastávajú odklony od spisovnej normy, vynecháva sa koncové y na konci základu. Zaznamenali sme príklady typu Fábrová, Šiagová, Žemberová. Vel'mi často, nielen v ústnej podobe ale aj v písanej, $\mathrm{v}$ rozličných dokladoch namiesto samohlásky tvrdého y sa zapisuje spoluhláska j, napr. Tordajová, Žilajová.

Treba pripomenút', že v našom výskume sme zaznamenali prípady, ked' jedno priezvisko je zapísané dvoma spôsobmi. Bežne sa používajú obe podoby, lebo to závisí od toho, kto je ako zapísaný do matriky narodených. Existujú doklady používania priezviska s mäkkým -i na konci základu, respektíve priezvisko so zakončením na -y, napr.: Fábri-Fábry, Feldi-Feldy, Žemberi-Žembery; priezviská zakončené na samohlásku -o oproti priezviská so zakončením na samohlásku -a: Beňa - Beňo, Benka - Benko, Haška - Haško, Grn̆a - Grn̆o, Detka - Detko, Franka - Franko. Ďalšiu skupinu tvoria priezviská s nulovým zakončením oproti -a: Bobot-Bobota, Cefer-Cefera, Čiep - Čiepa, Dýr-Dýra, Gábor-Gábora. Pri tvorení ženských podôb priezvisk z oboch tvarov neexistujú rozdiely. Prechýlený tvar bude napr. Benková aj od mužskej podoby Benko ale aj Benka. Štvrtú podskupinu tvoria priezviská, ktoré majú rozdielne podoby pre mužský rod. Jeden tvar je s nulovým zakončením a iný s -i napr.: Királ' - Királi, Koroš - Koroši, Moháč - Moháči, Mučaj-Mučaji, Očovej-Očoveji, Parkán̆ - Parkáni, Pihon̆ - Pihoni, Rožnaj - Rožnaji. Pri odvodzovaní prechýlených ženských podôb na rozdiel od predchádzajúcich dokladov dôležité je zakončenie. Prechýlené podoby 
v oboch prípadoch tvoríme rovnako, pridaním koncového -ová. Lenže ženské priezvisko z mužského tvaru s nulovým zakončením bude Korošová a z mužského priezviska, ktoré sa končí na samohlásku -i, bude mat' tvar Korošiová. Pri troch priezviskách Halabrín - Halabríni, Kubány - Kubáni, Severíny - Severíni nielen, že existuje rozdiel v prechýlenej podobe, ale aj vo výslovnosti. Jeden tvar sa vyslovuje tvrdo, lebo na konci základu stojí tvrdá spoluhláska, resp. tvrdá samohláska Halabrínová, Kubányová, Severínyová a pri výslovnosti druhého tvaru prechýlenej ženskej podoby nastáva zmäkčovanie, vyslovujeme mäkko: Halabríniová, Kubániová, Severíniová.

1.7. Do tejto podskupiny sme zaradili priezviská, ktoré sa končia na samohlás$\mathrm{ku}-\mathrm{o}$, resp. -e. Je to málopočetná skupina priezvisk, ide o priezviská cudzieho pôvodu, $v$ rámci ktorej sa ženské prechýlené podoby tvoria pridaním koncového -ová na tvar mužského priezviska. V našom výskume sme zaznamenali tieto: Fekete - Feketeová, Forro - Forroová, Lilge - Lilgeová, Loče - Ločeová, Lovre - Lovreová, Mate - Mateová, Starke - Starkeová, Werle - Werleová. V rámci tejto skupiny vyskytuje sa nezvyčajné zoskupenie hlások samohláska + samohláska, ktoré nie je bežné pre slovenský jazyk. Pri tomto type ženských priezvisk sme zaznamenali v každodennej praxi odklon od spisovnej normy, namiesto tvaru Feketeová, Werleová sa bežne používajú podoby Feketová, Werlová.

2. Druhú skupinu tvoria priezviská, ktoré majú podobu prídavných mien. Priezviská tohto typu sú frekventované vo vojvodinskom prostredí. Mužská podoba priezviska sa končí na tvrdé y, krátke alebo dlhé, čo závisí od dížky predchádzajúcej slabiky. Také priezviská sú: Agársky, Bánsky, Bád’onský, Biely, Cinkotský, Dobrocký, Dubovský, Duurčiansky, Kevenský, Múdry, Plachtinský, Pokorácky, Rybársky, Semártonský, Sirácky, Šipický, Teplý. Prechýlené ženské priezviská tvoria sa rovnako ako aj prídavné mená ženského rodu, pridaním koncovky -á, -a, -ia. Frekventovaná je koncovka -á, napr.: Bád’onská, Cinkotská, Dobrocká, Dubovská, Kevenská, Plachtinská, Semártonská, Šipická, Teplá. Rovnako ako aj pri prídavných menách sa dodržiava pravidlo o rytmickom krátení, ak je predchádzajúca slabika dlhá, pridáva sa krátka koncovka: Agárska, Bánska, Biela, Ďurčianska, Múdra, Pokorácka, Rybárska, Sirácka a ak sa základ končí na mäkkú spoluhlásku, pridáva sa koncovka -ia (doklady tohto typu sme nezaznamenali vo vojvodinskom prostredí). V praxi sa vel'mi často môžeme stretnút' s podobami Bád’onsková, Durčianskova, ked' prechýlené podoby priezvisk sa tvoria na základe predchádzajúceho modelu, pridaním -ová, ked’ priezvisko má podobu podstatného mena. Iné pravidlá pri tvorení ženskej podoby platia v prípade, ked' priezvisko má podobu prídavného mena.

V praxi sa stretávame aj s dokladmi dvojčlenných ženských priezvisk. V slovenčine obe majú prechýlenú ženskú podobu. Vo väčšine prvé priezvisko je dievčenské a to druhé si žena preberá od manžela po uzavretí manželstva (aj ked' sú aj iné možnosti v súlade so zákonom). Také dvojčlenné priezviská sa píšu so spojovníkom, napr.: Berédiová-Stupavská, Boldocká-Grbićová, Dorčová-Valtnerová, Kotvášová-Jonášová, Stankovićová-Kriváková, Šimáková-Speváková, Tomanová- 
Makanová, Valentová-Belićová. V uvedených dokladoch okrem slovenských priezvisk v dvojčlenných priezviskách sa vyskytli aj srbské podoby, ktoré sa prispôsobujú zákonitostiam slovenského jazyka, srbské priezvisko nadobúda prechýlenú podobu s koncovým -ová (Grbićová, Belićová, Stankovićová). Na Slovensku je prax iná. Poradie mien vo zdvojenom priezvisku je nasledujúce: na prvom mieste sa uvádza nadobudnuté priezvisko (po manželovi), na druhom mieste rodné priezvisko manželky.

V slovenčine pri použivaní cudzích ženských priezvisk z jazykov, ktoré prechyl’ovanie nepoznajú, vzniká zásadný problém: prechyl’ovat' tieto mená, alebo nie? Táto otázka bola aktuálna aj skôr, nielen u nás, ale aj na Slovensku, a ani v súčasnosti nemôžeme sa l'ahostajne správat' ked' ide o prechyl'ovanie. Gramatický rod priezvisk je v slovenčine odvodený od prirodzeného rodu. To znamená, že sa uplatňuje dichotómia mužský - ženský, pričom rozlíšenie rodu má aj svoje formálne vyjadrenie - pri ženskej podobe je to zakončenie -ová, resp. -á/-a. Ako uvádza Martin Ološtiak (2001) „,priezviská teda v spisovnej slovenčine plnia dve základné funkcie: identifikáciu osoby a identifikáciu pohlavia.“ (s. 293) Ďalej jazykovedec Ološtiak uvádza, že v súvislosti s otázkou prechyl’ovania existujú dva protichodné názory, dva postoje, extralingválne a intralingválne. Tí, ktorí sú za neprechyl’ovanie, sú vo väčšine nelingvisti. Druhú skupinu názorov reprezentujú väčšinou lingvisti, tieto postoje sú intralingválne motivované. Opodstatnený sa zdá byt' tento spôsob, lebo komunikácia sa uskutočňuje v slovenskom jazyku a medzi Slovákmi, preto je aj prechyl’ovanie cudzích priezvisk, konkrétne v našom prípade hlavne srbských, primeraným jazykovým aktom, ktorý má svoju oporu v kodifikácii. V písaných a hovorených médiách vysielaných po slovensky sme zaznamenali konkrétne tieto srbské priezviská v prechýlenej podobe, napr.: $M i$ hajlovićová, Dragašová, Đukićová-Dejanovićová, Kostićová, Lazarevićová, Maksimovićová, Marušićová, Rajićová, Vujačićová.

Prečo hovoríme o prechylovaní priezvisk? Prechýlením mužského priezviska sa v slovenskom kontexte signalizuje prirodzený ženský rod a umožňuje sa ohýbanie priezviska tak, ako je to v súlade s platnou kodifikáciou. Používanie koncovky -ová v ženských priezviskách je prirodzenou súčast'ou slovenského jazyka, lebo je flektívny jazyk, čo znamená, že vzt’ahy medzi slovami sa vyjadrujú príslušnými tvarmi slov, konkrétne, mená sa skloňujú, rozlišujeme ohýbacie prípony. Na rozdiel od analytických jazykov, v ktorých sa vztahy medzi slovami vyjadrujú pomocou osobitných slov, členov a predložiek. Preto v slovenčine je jazykovo, gramaticky správna a korektná veta Rozprávala som sa s kolegyňou Hud'anovou, Mitićovou a nie Rozprávala som sa s kolegyňou Hud'an, Mitić. Prechylovanie ženských priezvisk si vyžaduje slovenská gramatika, aby sa ženské priezvisko prirodzene začlenilo do slovenskej vety.

Zmienila by som sa o tom, aká je prax pri prechyl’ovaní ženských priezvisk u nás, vo vojvodinskej oblasti. Príslušníci slovenského jazykového spoločenstva majú právo používat' svoj materinský jazyk a podla toho majú právo zapísat' si svoje meno a priezvisko podl'a pravidiel, a noriem slovenského jazyka. Či tak 
postupujú, to je už individuálne. Vel'mi často sa stáva, že v matrike narodených ženské priezvisko je zapísané bez prechýlenej podoby, teda rovnako ako aj mužské. Čo sa potom deje pri používaní, pri zapisovaní priezviska neskoršie? Ak by sa odstúpilo od pôvodného zapisovania, čiže ak by sa použila prechýlená podoba. Uvediem príklad: ak sa študentka zapíše na Filozofickú fakultu, odbor slovakistika a vo výpise z matriky narodených píše napr. Jana Kovač. V priebehu štúdia všetci ju budú oslovovat' a oslovujú spomenutú študentku Jana Kováčová. Ked' napríklad píše písomnú prácu z niektorého predmetu podpíše sa znovu Jana Kováčová. V evidencii o zložených skúškach bude znovu uvedené Kováčová. Avšak po ukončení štúdia bude diplom vydaný na meno Jana Kovač. Čo by sa stalo, ked' by diplom znel na Kováčová? Vtedy už nejde o tú istú osobu. To znamená, že je potrebné rozlišovat' oficiálny, úradný a neoficiálny, neúradný kontext. Rovnako tak platí, že aj slovanské prechýlené priezviská v jazykoch bez prechylovania rešpektujú tieto podoby a nezasahujú do priezvisk. Tak v týchto dňoch vo vysielaniach po srbsky som zachytila vlastné meno a priezvisko Kristina Georgijeva a nie Georgijev. Otázku podobného typu mi položili zo základnej školy z Kysáča. Žiačka sa podpísala na kontrolnú úlohu Sara Gaško. Učitel'ka tu zasiahla a opravila Sára Gašková. Otázka znie, či postupovala správne. Áno, v tomto kontexte píšeme prechýlenú podobu, bez ohl’adu na zápis $\mathrm{v}$ matrike narodených. V tejto súvislosti vyvstáva otázka ako písat' mená a priezviská na tablo? Samozrejme, mám tu na mysli tablo s fotografiami žiakov, ktorí ukončili školu s vyučovacím jazykom slovenským. Ako tu zapisovat' mená a priezviská. Uvediem konkrétne doklady, mená a priezviská. Na jednom z nich pod fotografiou žiačky bolo napísané: Daniela Stupavsková. Ide o prechýlenú podobu a uvádzam ju preto, lebo je nenáležite použitá prechýlená podoba. Mužské priezvisko má formu prídavného mena a ženské priezviská sa pri tomto type netvoria príponou -ová ale pridaním -á, teda správna podoba znie Daniela Stupavská. Podl'a môjho názoru by sa v prípade ak sa uplatňuje prechyl'ovanie, malo by sa uplatňovat' dôsledne a konzistentne. Bolo by vhodné vyhnút' sa prípadom kedy je jedno priezvisko prechýlené a iné hned' vedl’a neprechýlené: Tamara Činčuráková, Veronika Fačarová, Grňová, Cerovská, Daniela Hansmanová, Maja Mad’arová, Tatiana Fejdiová a d’alšie priezviská zapísané v mužskej podobe: Iveta Makan, Irena Molnar, Lidija Mandač, Ivana Marko, Miroslava Šimovič, Aleksandra Bohuš, Anna Nikolajević, Michaela Čiliak, Aleksandra Čipkár, Tatjana Jurík Marčok. Všimla som si to isté tablo. Vel'mi ma prekvapilo, ked' srbské priezvisko bolo zapísané v prechýlenej podobe Irena Ilićová a rýdzo slovenské, d'alšie, v mužskej podobe. Konkrétne ide o maturantov petrovského gymnázia. V tomto kontexte by som sa zmienila aj o zapisovaní mien. V slovenčine, podl'a slovenského pravopisu meno Alexandra (môžeme si to overit' v najnovšom Slovníku súčasného slovenského jazyka ag s.105) píšeme s x, rovnako ako prax, syntax, luxus a pod. Rovnako tak aj ženské krstné meno Lýdia by sa malo zapísat's y a ia na konci slova (Slovník súčasného slovenského jazyka hl s. 1044). Alebo d’alší doklad: krstné meno Anna zapísané so zdvojeným nn a priezvisko v mužskej podobe (Anna Nikolajević). Zmienim sa aj o mene Pal'o (Pal’o 
Belička, riaditel' gymnázia). Meno by sa malo zapísat' v oficiálnej podobe Pavel. Domácka - hypokoristická podoba Pal’o je bežná v neoficiálnom styku, v hovorenej reči a v umeleckých kruhoch. Je to príznaková podoba krstného mena, rovnako tak, ako ked' by sme povedali alebo zapísali do úradného dokladu Pal'ko. Krstné meno Tatiana bolo rozdielne zapísané, s dvojhláskou ia a so spoluhláskou j. Podl'a pravidiel slovenského jazyka treba zapisovat's dvojhláskou ia: Tatiana. Doklad mám aj z písaných médií. V týždenníku Hlas l’udu č. 16-17 (19.-26.4. 2014 s. 22) pod fotografiou bolo zapísané takto: Željko Čapel’a. Predpokladám, že všetci vel'mi dobre vieme, že ide o Slováka z Dobanoviec, ktorý sa zapája do verejného života. Jazyková redaktorka $\mathrm{v}$ tomto prípade mala jednoducho transkribovat' srbskú spoluhlásku lj.

Téma prechyl’ovania priezvisk je spätá aj s brožúrkou Vojvodina miesto významných Sloveniek, ktorú pripravila Akadémia podnikania žien Báčsky Petrovec. Do brožúrky je zaradených pätnást' žien. Je to trojjazyčná publikácia - text je napísaný po slovensky, po srbsky a po anglicky. Mená a priezviská sa uvádzajú po slovensky a po srbsky. Je otázne, podl'a čoho sa riadili autorky pri zapisovaní priezvisk. Nepostupovali jednotne. Ked' ide o slovenské znenie, tu dôsledne uplatňovali prechylovanie, napr.: L’udmila Hurbanová, Eržika Mičátková, Adela Cajaková-Petrovičová, Zuzana Chalupová, Adela Greisingerová-Kubányová, Mariena Czoczeková-Eichardtová, Ludmila Kvačalová, Mária Šišková-Maňa, Zuzka Medved'ová, Anna Pixiadesová, Zuzana Kardelisová, Anna Benková, Božena Škul'cová, Mária Kičiňová,Olga Garayová-Babylonová, ale ked’ ide o srbskú podobu, tu sa vyskytujú aj s prechýlené podoby Ljudmila Hurbanova, Adela ČajakovaPetrovičova, Zuzana Halupova... ale aj neprechýlené podoby Eržika Mičatek, Marjena Čoček-Ajhart, Zuzana Kardelis. Tu by som upozornila na Ana Pixiadesova v srbskom znení. V srbčine neexistuje písmeno $\mathrm{x}$, preto jediný možný spôsob transkripcie je Piksiadesova.

V príspevku sme sa pokúsili prakticky odôvodnit' transkribovanie slovenských podôb priezvisk do srbčiny. Naznačili sme rozdiely pri transkribovaní podl'a normatívnych príručiek. V druhej časti sme sa zamerali na tvorenie prechýlených podôb nielen slovenských priezvisk, ale aj inojazykových v slovenskom kontexte a prípadné odklony. Mužské priezviská majú najčastejšie formu substantív ako pomenovaní samostatne existujúcich substancií. Len zriedka majú adjektívnu formu (Pucovský). Ženské priezviská majú všetky formu privlastňovacieho prídavného mena na -ova/-ová, -á/-a. Tak môžeme konštatovat', že tvorenie ženských priezvisk má dve stránky - právnu úpravu a jazykovú prax. Máme možnost' vybrat' si prechýlenú alebo neprechýlenú podobu priezviska. Je potrebné mat' na zreteli, že prechyl’ovanie je záležitost’ou jazyka, gramatiky a nie politiky a práva. Preto o prechyl’ovaní treba hovorit' ako o jazykovom probléme. V slovenčine je prechýlená podoba najekonomickejším a najjednoduchším ukazovatel'om feminatívnosti.

V jazykovej praxi je rozhodujúci typ jazykovej komunikácie. V oficiálnej komunikácii by sa malo priezvisko zhodovat's úradnou formou a v neoficiálnej komunikácii by sa malo pripúštat' prechylovanie aj pri neprechýlených priezviskách. 
Problematika prechyl’ovania sa stala aktuálnou aj na Slovensku v roku 2012 v súvislosti s pripravovanou novelou matričného zákona, ktorá ponúka ženám možnost' rozhodnút' sa, či chcú mat' v matričnom zápise príponu -ová v priezvis$\mathrm{ku}, \mathrm{tj}$. či chcú mat' prechýlené priezvisko. Novela zákona nebola schválená, pretože bola v rozpore so zákonom o štátnom jazyku, ktorý takýto zásah do systému slovenského jazyka nedovol'uje. Zákon dáva možnost' zmenit' si priezvisko, ale za poplatok. Ďalej žena si môže zapísat' priezvisko v mužskom tvare v prípadoch, ak je žena inej národnosti, ak je štátnou občiankou aj iného štátu. Sú známe prípady, ked' Slovenky z Vojvodiny získali štátne občianstvo Slovenskej republiky. Pri zápise do dokladov bola možná len a len prechýlená podoba priezviska a pri mene bola uplatnená transkripcia Suzana $\rightarrow$ Zuzana.

Na záver je možné skonštatovat', že jazyk sa vyvíja. Vyvíja sa aj pomenovacia sústava osobných mien a zmena v kodifikácii by mala byt' opodstatnená len vtedy, ak je to dlhšie zaužívané pri pomenúvaní osôb, tj. v praxi. Ak by sa používali priezviská bez prechylovacej prípony, bol by to umelý zásah do pomenovacej sústavy, ktorý nemá tradíciu a nie je ani podložený dlhodobým ustáleným stavom $\mathrm{v}$ praxi a to $\mathrm{v}$ spoločenskom úze a $\mathrm{v}$ administratívno-právnej oblasti. Aby sa nejaký jazykový jav stal platnou normou, musí íst' o rozšírený a ustálený jav a nie iba módny trend.

Mienime, že treba využívat' právo, ktoré majú národnostné menšiny v Republike Srbsko. Používat' svoje meno a priezvisko vo svojom jazyku a podl'a platných noriem a pravopisu slovenského jazyka. Navrhujeme, aby sa pri zapisovaní mien a priezvisk v srbčine dôsledne uplatňovalo a označovalo zmäkčovanie. Podoby ženských priezvisk používat' $\mathrm{v}$ prechýlenej podobe. Aj srbské priezviská $\mathrm{v}$ slovenskom kontexte používat' v prechýlenej podobe.

\section{LITERATÚRA}

Dudok, D. (2001). Priezviská Slovákov v Juhoslávii. Nový Sad: Spolok vojvodinských slovakistov.

Dudok, D. (2006). Pôvod Hložančanov z hl’adiska ich priezvisk. U: Hložany 1756-2006. Zborník prác pri príležitosti 250. výročia príchodu Slovákov do Hložian. (s. 261-271). Hložany: MOMS; Báčsky Petrovec: Kultúra.

Dvonč, L. \& Horák, G, \& Miko, F. \& Mistrík, J. \& Oravec, J. (1966). Morfológia slovenského jazyka. Bratislava: SAV.

Hlas l’udu, informačno-politický týždenník. č. 16-17, 19.-26.4. 2014.

Kovač, V. \& Radaković, J. (2013). Vojvodina miesto významných Sloveniek. Bački Petrovac: Akademija ženskog preduzetništva.

Lomianský, P. (2006). Menšinové práva v oblasti úradného použivania jazyka a písma. Nový Sad, Belehrad: Fórum Slovákov - FORS, Građanske inicijative.

Majtán, M. (2014). Naše priezviská. Bratislava: VEDA, vydavatel'stvo Slovenskej akadémie vied.

Marićová, A. \& Týr, M. \& Makišová, A. \& Týrová, Z. (2011). Transkripcia priezvisk zo slovenčiny do srbčiny. Nový Sad: Národnostná rada slovenskej národnostnej menšiny. 
Ološtiak, M. (2001). O prechyl’ovaní cudzích priezvisk v slovenčine. Slovenská reč, 66, č. 5 s. $292-298$.

Ološtiak, M. (2010). Morfológia vlastných mien. U: Morfologické aspekty súčasnej slovenčiny. Editor Juraj Dolník. (s. 97-134). Bratislava: Veda, vydavatel'stvo Slovenskej akadémie vied.

Ološtiak, M. (2011). Slovotvorba prevzatých vlastných mien v slovenčine II. Tvorenie derivátov od osobných mien. Kultúra slova, 45, 2011, č. 2, s. 65-78.

Pešikan, M. \& Jerković, J. \& Pižurica, M. (2013). Pravopis srpskoga jezika. Novi Sad: Matica srpska.

Pravidlá slovenského pravopisu (2000). Bratislava: Veda, vydavatel'stvo Slovenskej akadémie vied.

Pravidlá slovenského pravopisu s abecedným a pravopisným slovníkom. Vydala Matica slovenská nákladom Štátneho nakladatel'stva v Prahe 1931. 364 s.

Slovník súčasného slovenského jazyka ag (2006). Bratislava: Veda, vydavatel'stvo Slovenskej akadémie vied.

Slovník súčasného slovenského jazyka hl (2011). Bratislava: Veda, vydavatel'stvo Slovenskej akadémie vied.

Týr, M. (2004). Meno a národná identita. Slovenčina v praxi. Štúdie z konfrontačnej a aplikovanej lingvistiky. (s. 38-45). Nový Sad: Futura publikacije.

Ana Makišova

\section{PISANJE SLOVAČKIH PREZIMENA U SLOVAČKOM I SRPSKOM}

\section{REZIME}

Pripadnici nacionalnih zajednica u Vojvodini imaju pravo da u matične knjige rođenih pored službenog jezika srpskog, mogu upisati svoje ime i prezime i na svom maternjem jeziku, konkretno slovačkom, i zbog toga je neophodno poznavanje pravila transkripcije iz jednog jezika na drugi. U radu smo prikazali transkribovanje slovačkih prezimena na srpski jezik, i kako zapisujemo pojedine slovačke grafeme (d', t', l', ň, ia, ie, iu, ô, y) u srpskom jeziku. Svaku grafemu smo argumentovali primerom.

U drugom delu rada prikazali smo načine građenja prezimena oblika za ženski rod u slovačkom jeziku. Ženski oblik se gradi od muških oblika dodavanjem sufiksa -ová, -ská, -cká. U praksi prilikom upotrebe postoje određena odstupanja od standardnog jezika.

U trećem delu rada prikazali smo primenu prezimena u ženskom obliku u praksi. Naveli smo primere, gde dolazi do odstupanja od standardnog jezika, i gde je vidljiv uticaj srpskog jezika.

Ključne reči: prezime, slovački jezik, srpski jezik, ženski oblik prezimena. 
Ana Makišová

\section{WRITING SLOVAK SURNAMES IN THE SLOVAK AND SERBIAN CONTEXTS}

\section{SUMMARY}

Members of national minorities in Vojvodina have the right to add to the birth register their name and surname in their mother tongue (Slovak, in this case) beside the name in the official language, Serbian. For that reason it is necessary to know the rules of transcription from one language to another. The paper presents the transcription of Slovak surnames into Serbian, that is the way to adapt certain Slovak graphemes (d', t', l', ň, ia, ie, iu, ô, y) in the Serbian language. Every grapheme is illustrated with an example.

The second part of the paper presents the ways female surnames are formed in the Slovak language. The female surnames are formed by adding the suffixes -ová, -ská, -cká to the male surnames. In practice, however, there are certain deviations from the standard language.

In the third part of the paper we discuss how female surnames are used in practice. We list examples which illustrate deviations from the standard language under the influence of the Serbian language.

Key words: surname, Slovak language, Serbian language, female form of surnames 